\title{
The Study on Innovation and Entrepreneurship Curriculum System Construction under "Government-University-Enterprise" Collaboration Mechanism
}

\author{
Bing Bai ${ }^{1}$, A-jun Guo ${ }^{1}$,Xiao-wei Wang ${ }^{1, *}$ \\ ${ }^{1}$ Beihua University ,Jilin, China \\ *Corresponding author
}

Keywords: "government-university-enterprise" collaboration, innovation \& entrepreneurship, curriculum system.

\begin{abstract}
University innovation \& entrepreneurship curriculum system construction is both the core issue and the basic guarantee of talent cultivation. This paper analyzes the basic status of university innovation \& entrepreneurship education and proposes the basic strategy for perfecting innovation \& entrepreneurship system from five perspectives of deepening talent cultivation mode, improving innovation \& entrepreneurship education contents, forming three-grade management, reinforcing teaching staff construction, building capacity cultivation supporting platform respectively in the background of "government-university-enterprise” collaboration.
\end{abstract}

\section{Introduction}

It's hard to start an undertaking and only struggle can make a success. Nowadays, the talents with innovation capacity has become the "core productivity "[1] of the production of an innovative country, universities take on the historic task of cultivating a great many high-quality innovative and entrepreneurial talents, innovation \& entrepreneurship curriculum is the main way to carry out innovation \& entrepreneurship education. Scientific and rational innovation \& entrepreneurship curriculum construction in the core issue of innovative talent cultivation and also the fundamental guarantee of talent training. A practical promotion of innovation \& entrepreneurship curriculum system construction is the urgent demand for our country's innovation-driver development strategy implement, the essential way to advance teaching reform of higher education and also the important measure to promote college graduates’ high-quality employment \& entrepreneurship.

\section{The current situation of university Innovation \& Entrepreneurship Education}

In 1989, UNESCO put forward the concept of entrepreneurship education the international symposium on "education facing the 21st century" [3], in 1998 , at the world higher education conference , it further pointed out that "higher education should mainly cultivate entrepreneurship students' entrepreneurial skills and initiative spirit" [4], the same year, Tsinghua University held the first domestic business plan competition [5], then held the first "Challenge Cup" national college students business plan competition, in 2000, Tsinghua University introduced the policy of "Permission for college students to drop out of school for entrepreneurship " [6], thus a climax of college students entrepreneurship was initiated in our country.In 2002, nine domestic universities 
take the lead in developing innovation entrepreneurship education pilot work, step by step tracking out entrepreneurship education mode of "classroom type", "practice type", "comprehensive type", "foster type" ,"one primary with many supporting elements" and so on in practice [7]. In 2006, at the fourth national conference on science and technology, the development of innovative talents resources was noted again. By 2015, there have been $82 \%$ of universities in the country carrying out innovative education on compulsory or elective courses, establishing innovative venture capital up to 1.22 billion yuan [8]. Chinese universities and colleges have conducted a diversity of exploration on talent cultivation, most universities have set up relevant entrepreneurship courses, specialized institutions of innovation \& entrepreneurship education, a platform of innovation \& entrepreneurship practical teaching and hatch, and have achieved some effective results.

However, because different colleges and universities have different regional economic development condition, education resources, school-running orientation and talent training specifications, innovation \& entrepreneurship education courses also have different settings. As a whole, innovation \& entrepreneurship education curriculum system construction of colleges and universities still have some common problems:

\section{(1) Unclear goals of innovation \& entrepreneurship education curriculum system construction}

The accurate pinpoint of innovation \& entrepreneurship curriculum system construction is the promotion of deepening education and teaching reform in colleges and universities, the effective means for universities to fully promote and improve students' comprehensive quality competitiveness, and also the inevitable measures to implement the relevant national policies. But in the process of curriculum system construction, various universities should be based on their own educational practice, as well as the different needs of the regional economy to construct the curriculum system, avoiding copying the existing curriculum model.

\section{(2) Innovation \& entrepreneurship isolation, failed to combine the discipline advantage with s ystem construction}

In terms of curriculum provision, the courses related to entrepreneurship set up by most universit ies are only one or several traditional public compulsory courses and elective courses, neither to dev elop innovative entrepreneurial characteristic curriculum with its advantages of disciplines, nor to combine organically with entrepreneurship education, they cannot link up effectively with other cou rses, thus the courses are relatively isolated. This will inevitably affect students' entrepreneurship aft er graduation with their professional knowledge background.

\section{(3) Insufficient construction of teachers' team}

Teaching staff is the main condition of running a school, also the key to ensure the quality of tale nt cultivation. It is the core content of construction of teachers' team to cultivate double type teach ers with the ability of both imparting theoretical knowledge and professional skills and practical abil ity. At present, the lecturers of the university innovation \& entrepreneurship courses teach too much in theory teaching, lacking operation training. 


\section{The advantages of the "government-university-enterprise " collaboration}

In the peak forum of global famous entrepreneurship universities on Chengdu global innovation \& entrepreneurship trade fair in 2015, the training mode of "government-university-entrepreneur co operation" was put forward. It refers to collaboration of the government, universities, enterprises an $\mathrm{d}$ industries in the aspects of function and resource advantages, it is a innovative system, setting mar ket as orientation , government as guidance, enterprise as the main body, universities and scientific research institutes as dependence through the transformation of scientific and technological achieve ments, cooperative research and development, as well as joint research. With the training mechanis $\mathrm{m}$ of government-university-enterprise, the government departments provide policy support and gua rantee for the guide at the same time they can also give full play to its own wide contact surface, we ll-informed and high competency advantage, which contributes to government-university-enterprise cooperation, follow its actual effect as well as coordinate and solve problems existing in the cooper ation. "Government-university-enterprise " collaboration is beneficial to the close contact of stude nts and enterprises, the superposition of the effective theory and practice, significant improvement o f students quality, university development, enterprise access to adequate and stable high-quality tale nt security, and the government for its corresponding public interest, finally achieving tripartite winwin situation.

\section{Countermeasures of innovation \& entrepreneurship curriculum system construction}

(1) Deepening the reform of talent cultivation model, forming a long-term mechanism in favou $r$ of the students' innovative practice ability

Entrepreneurship education can be included in the whole professional talent training scheme of s chool, increasing the proportion of comprehensive, designing experimental projects and elective co urses, strengthening personalized applied talent training, increasing the practical teaching content ra tio, highlighting students' entrepreneurship training. Implement flexible length rules to allow studen ts to drop out of school for entrepreneurship, in order to improve the quality of personnel training an d enhance their social fitness.

\section{(2) Reforming the curriculum system, improving the content of entrepreneurship education}

Blend entrepreneurship education in specialized backbone courses, establishing a multidisciplina ry cross curriculum system, developing and setting up compulsory courses and elective courses of $r$ esearch methods, academic frontiers, entrepreneurship fundamentals, employment guidance and so on facing all the students, and incorporating them into the credit management.

\section{(3) Strengthening the teaching staff construction, improving the overall level of education}

Universities can improve the teaching staff construction through a variety of ways, require and d esignedly arrange middle-aged and young teachers to participate practice exercise in enterprises, int ensify efforts to send professional teachers to participate in business training at or above the provinc ial level, helping to form a good situation of strong teaching staff, plural subject coverage and guide means, and rich guide content. Universities can also adopt university-enterprise cooperation pattern , hire long-term entrepreneurial education experts, famous scholars and entrepreneurs outside scho ol to develop college students' entrepreneurship education activities, hire professional guidance insti tutions to fully participate student entrepreneurship, provide them entrepreneurship training, entrepr 
eneurship practice, project argumentation, registration, financial management, advisory services and other system supporting measures.

\section{(4) Constructing ability training support platform, exploring a new pattern}

Universities can unite their own actual situations and the existing resources, such as provincial a nd national experimental teaching demonstration center, students' science and technology innovatio $\mathrm{n}$ base, practice base outside school and other platforms, meeting the requirements of students entre preneurship training project implement.

\section{Conclusion}

Universities should improve the talent cultivation scheme, venture entrepreneurship education into the whole teaching process, further take all kinds of bases, carriers and teams as a whole, form effective links from innovation to entrepreneurship, from base supports and carrier design to the team organization, further straighten out the mechanism, realize the effective linkage of science and technology park, entrepreneurship park and industrial park, further enhance the directionality of the entrepreneurial activity, implement close joint with the demand of regional development, vigorously promote entrepreneurship education reform, and practically improve the contribution ratio to economic and social development of the regions where the universities are located.

\section{Acknowledgement}

This paper is Social science research project in 13th Five-Year of Jilin Provincial Department of Education: College Students' socialist core value concept of experiential education education model based on the research results. (no:2016-36)

\section{References}

[1], Jin Haiyan, Xie Hongmei. Carry forward the spirit of seeking truth and innovation. Ex plore a distinctive entrepreneurial education model. Summarize and share the experience of entrepreneurship education in Zhejiang University. [J]. Chinese university students, 2 008, (22): $55-56$

[2], Li Hexuan. Research on entrepreneurship practice teaching [J]. economist, 2016, (09): 2 28-229.

[3] Li Yong, Duan Qionghui, Hu Xingang. The connotation of innovation and entrepreneurs hip education and the history of the [J]. occupation technology, 2017,16 (08): 9-12

[4] Lin Yekun. Based on the "public entrepreneurship peoples innovation under the backgro und of private college education management of higher education path selection [J]. jou rnal, 2017, (16): 32-34+37.

[5], Wang Peng, Wang Zheng. Text analysis of entrepreneurship education policy in China [J]. ideological and theoretical education, 2017, (08): 91-96.

[6] She Dandan, the Song Dynasty China. Students start to implement the policy on the sta tus quo of [J]. contemporary economy, 2016, (33): 104-105.

[7], Wang Cuie. New development, problems and strategic choice of entrepreneurship educat 
ion in Chinese universities [J]. Journal of Jiangsu Institute of Economic\&Trade Technol ogy, 2016, (03): 74-76.

[8] Xue Chenglong, Lu Caichen, Li Duanmiao. "12th Five-Year" during the review and Ref lection on innovation and entrepreneurship education in Colleges and Universities -- Bas ed on the analysis of higher education "third party assessment report" [J]. China higher education research, 2016, (02): 20-28+73. 